потенціалу підприємства [Текст] / O.C. Іванілов, І.Л. Плєтникова, Д.М. Дячков // Вісник економіки транспорту i промисловості. - №15-16. - 2006. - С. 67 74.

10 Плєтникова І.Л.( Назаренко І.Л.). Удосконалення методики оцінки кадрового потенціалу підприємств залізничного транспорту [Текст] / І.Л. Плєтникова // Вісник Хмельницького нац. ун-ту. Економічні науки. - 2008. - №4, т. 2. - С. 52 56.
11 Назаренко .Л. Оцінка та оптимізація кадрового потенціалу дирекції залізничного транспорту [Текст] / І. Л. Назаренко // Вісник економіки транспорту і промисловості. - 2013. - Вип. 44. - С. 70 74.

12 Харун О. А. Оцінка трудового потенціалу промислового підприємства / O. А. Харун // Наукові праці Кіровоградського національного технічного університету. Економічні науки. - Вип. 25. - 2014. - С. 92-97.

УДК 658.012.8

\title{
ПРІОРИТЕТИ ЗМІЩНЕННЯ ЕКОНОМІЧНОЇ БЕЗПЕКИ ПІДПРИЄМСТВ МАШИНОБУДУВАННЯ В НАПРЯМУ ПРОТИДІЇ РЕЙДЕРСТВУ
}

\section{Писаревський М. І., аспірант (ХНУМГ імені О.М. Бекетова)}

Метою статті є виявлення основних загроз економічній безпеизі підприємств машинобудування та окреслення основних напрямів ї зміцнення в напряму протидіi рейдерству. На основі систематизаиії наукових праць вітчизняних та зарубіжних вчених проаналізовано причини розвитку рейдерства в Україні. У результаті проведеного дослідження визначено основні передумов розвитку рейдерства та обтрунтовано пріоритетні напрями зміцнення економічної безпеки підприємств машинобудування в напряму протидії рейдерству.

Ключові слова: економічна безпека, підприємство, рейдерство, загрози, забезпечення економічної безпеки підприємства в напряму протидії рейдерству.

\section{ПРИОРИТЕТЫ УКРЕПЛЕНИЯ ЭКОНОМИЧЕСКОЙ БЕЗОПАСНОСТИ ПРЕДПРИЯТИЙ МАШИНОСТРОЕНИЯ В НАПРАВЛЕНИИ ПРОТИДЕЙСТВИЮ РЕЙДЕРСТВУ}

\author{
Писаревский Н. И., аспирант (ХНУГХ имени А.Н. Бекетова)
}

Целью статьи является выявление основных угроз экономической безопасности предприятий машиностроения и определение основных направлений ее укрепления в направлении противодействия рейдерству. На основе систематизации научных трудов отечественных и зарубежных ученых проанализированы причины развития рейдерства в Украине. В результате проведенного исследования определены основные предпосылки развития рейдерства и обоснованы приоритетные направления 
укрепления экономической безопасности предприятий машиностроения в направлении противодействию рейдерству.

Ключевые слова: экономическая безопасность, предприятие, рейдерство, угрозы, обеспечение экономической безопасности предприятия в направлении противодействию рейдерству.

\title{
PRIORITIES FOR STRENGTHENING ECONOMIC SAFETY OF MACHINE-BUILDING ENTERPRISES UNDER CONDITIONS OF REIDER
}

\author{
Pysarevskyi M., graduate student \\ (O.M. Beketov National University of Urban Economy in Kharkiv)
}

The aim of the article is an exposure of basic threats to economic security of enterprises of engineer and lineation of basic directions of her strengthening in the conditions of corporate raid. On the basis of systematization of scientific works home and foreign scientists are analysed reasons of development of corporate raid in Ukraine. As a result of undertaken a study certainly basic pre-conditions of development of corporate raid and priority directions of strengthening of economic security of enterprises of engineer are reasonable in the conditions of corporate raid, that gives an opportunity to choose the complex of the measures of organizationally-economic character, sent to maintenance of the proof functioning and development of enterprise in current and future periods. The prospects of further researches in this direction is a scientific ground of theoretical aspects of forming of effective mechanism of providing of economic security of enterprise in the conditions of corporate raid on the basis of analysis of the conceptual going near determination of essence description of separate elements of concept vehicle, namely concepts "economic security of enterprise" and corporate "raid". The improvement of concept vehicle will allow to form quality the tool of providing of economic security of enterprise is scientifically reasonable at direction of counteraction to the corporate raid.

Keywords: economic security, enterprise, corporate raid, threats, providing of economic security of enterprise at direction of counteraction to the corporate raid.

Постановка проблеми. Вітчизняні підприємства машинобудування в умовах інтеграційних змін внаслідок негативного впливу факторів зовнішнього і внутрішнього середовища втрачають традиційні ринки збуту, що створює загрози стабільному функціонуванню та подальшому розвитку. Високий ризик рейдерських захоплень через погіршення фінансового стану та недосконалість чинного законодавства в сфері корпоративного управління посилюють ризики господарської діяльності, провокують загрозу банкрутства та погіршення виробничих параметрів підприємства. Головним завданням ефективного управління підприємствами машинобудування $\epsilon$ забезпечення економічної безпеки, що сприятиме підвищенню рівня конкурентоспроможності, інвестиційної активності, прибутковості. Стабільний розвиток вітчизняного машинобудівного сектору забезпечує економічне зростання як окремих регіонів, так i держави в цілому, оскільки відіграє провідну роль в створенні матеріально-технічної бази вітчизняної промисловості та впровадженню досягнень науковотехнічного прогресу, інноваційних змін. В зв'язку 3 цим дослідження стану та визначення основних загроз економічній

Вісник економіки транспорту і промисловості № 59, 2017 
безпеці підприємств машинобудування України у напрямку протидії рейдерству $є$ актуальним та своєчасним завданням.

Аналіз останніх досліджень i публікацій. Проблеми забезпечення економічної безпеки підприємств досліджувалися в роботах вітчизняних економістів: 3. Варналія [1], О. Барановського [2], Н. Кузьминчук [2] та ін. Дослідженням функціонування підприємства в умовах протидії недружньому злиттю та поглинанню i оцінкою рейдерських загроз займалися Согрина Н.С. [3], Кірєєв О. [4] та ін. Теоретико-методичні основи формування механізму протидії недружньому поглинанню та злиттю підприємств розглянуто у роботах О. Бурбело [5], С. Молодецького [6], Б. Сребника [7], Ю. Щеглова [8], І.Ю. Зайцевої [9].

Виділення невирішених частин загальної проблеми. Разом 3 тим, актуальність проблеми забезпечення економічної безпеки вітчизняних підприємств машинобудування в складних умовах ведення господарської діяльності, негативного впливу факторів як внутрішнього так i зовнішнього середовища, рейдерських загроз полягає в необхідності визначення основних пріоритетів зміцнення економічної безпеки у напрямку протидії рейдерству.

Метою статті $\epsilon$ виявлення основних загроз економічній безпеці підприємств машинобудування та окреслення основних напрямів іiі зміцнення в напряму протидії рейдерству.

Виклад основного матеріалу дослідження. Об'єктами рейдерських атак в Україні дедалі частіше стають не лише слабкі підприємства, які самостійно не можуть вирішити економічні проблеми і знаходяться на грані банкрутства, а й фінансово привабливі i найбільш прибуткові, що володіють високоліквідними активами та стабільно працюють. Насамперед це стосується машинобудівної галузі як провідного сектора вітчизняної промисловості. За даними представників Антирейдерської асоціації України, за період 2010-2014 рр. від рейдерських захоплень постраждали близько 5 тис. підприємств, зокрема, рейдерські атаки були спрямовані на цілі галузі вітчизняної економіки, а щорічна сума операцій 3 незаконного перерозподілу майна становила близько 7 млрд. дол. [10]. Протягом 2014 р. відбулося декілька гучних рейдерських захоплень 3 використання рішень господарських судів для надання максимальної легальності недружньому поглинанню та злиттю підприємств. За результатами проведеного Українським інститутом дослідження екстремізму моніторингу рейдерських атак в Україні за січень-лютий 2015 p. зафіксовано 68 об'єктів власності, що піддалися рейдерським атакам [11]. За регіональною ознакою найменше об'єктів нападу (7 випадків) зафіксовано в Західному регіоні, в Центральному регіоні зафіксовано 21 спробу незаконного перерозподілу власності. Найбільша кількість рейдерських атак зосереджена в Південносхідному регіону (30 випадків), що пояснюється загрозами захоплення привабливих об'єктів внаслідок близькості до зони проведення АТО та використанням озброєних формувань добровольчих загонів для вирішення проблемних питань розподілу власності. Відповідно до офіційних даних в 2015 р. в Україні зафіксовано вже близько 3 тис. рейдерських захоплень підприємств, які переважно працюють в сфері роздрібної торгівлі, нерухомості та аграрного бізнесу [6, с. 11]. Протягом 2016 р. по країні прокотилася хвиля рейдерських захоплень підприємств аграрного сектору, a, за даними Міністерства економічного розвитку та торгівлі, в 2017 р. відкрито 44 карні справи щодо незаконного захоплення від 1 до 3 тис. гектарів землі. Зважаючи на дані опитування Центру Разумкова, відповідно до яких $78,3 \%$ 
громадян відчувають загрозу відчуження майна [12], проблема рейдерства стає все більш актуальною та потребує негайного вирішення, оскільки виступає значним бар'єром на шляху іноземного інвестора, перешкоджає припливу прямих іноземних інвестицій, негативно впливає на інвестиційний клімат та економічну безпеку суб'єктів господарювання.

Наведені дані свідчать про значні масштаби проблеми в сфері дотримання корпоративних прав та захисту інституту власності як найважливішого елементу ринкової економіки. На сьогодні постає проблема забезпечення високого рівня економічної безпеки підприємств машинобудування у напрямку протидії рейдерству, оскільки стабільний фінансово-економічний стан машинобудівного комплексу відіграє значну роль не лише для розвитку промисловості, але й для економіки в цілому. Проте, незважаючи на велику кількість досліджень, присвячених проблемі попередження загроз економічної безпеки підприємства в напряму протидії рейдерству, слід відзначити відсутність єдиного підходу до досліджуваних проблем.

На законодавчому рівні [13] визначено основні шляхи створення акціонерних товариств, до яких віднесено наступні: заснування, злиття, поділ, виділ чи перетворення. Злиття, в свою чергу, трактується як процес виникнення нового акціонерного товариства-правонаступника 3 передачею йому всього майна, всіх прав та обов'язків двох або більше акціонерних товариств одночасно 3 їх припиненням. Жодним чином не висвітлюється проблематика недружнього поглинання та злиття 3 огляду на необхідність зміцнення економічної безпеки підприємства та протидії рейдерським захопленням. Окремі автори під «злиттям» розуміють всю сукупність можливих варіантів злиття та поглинань, починаючи 3 дружнього поглинання аж до скупівлі абсолютно всіх активів підприємства 3 наступним їх перепродажем [14, с. 351]. Інколи відповідні операції об'єднуються поняттям «поглинання», що передбачає наступні способи злиття підприємств: злиття за взаємною згодою на основі рішення власників та керівництва через процес купівлі акцій; захоплення, які носять ворожій характер, і відбуваються шляхом купівлі акцій безпосередньо у акціонерів за завищеними цінами; встановлення контролю над радою директорів через голосування за дорученням без викупу контрольного пакету акцій.

Як зазначається науковцями у роботах [1, 5, 7] угоди по злиттю та поглинанню можуть носити як дружній так і недружній (ворожий) характер. У випадку дружніх угод злиття та поглинань об'єднання компаній відбувається за взаємною згодою їх керівників 3 метою досягнення наступних переваг: підвищення якості управління компанією; отримання синергетичного ефекту від об'єднання активів; диверсифікації бізнесу та його подальшого розвитку i зростання та ін. [8, с. 172]. Недружні угоди злиття та поглинань передбачають проведення відповідної процедури без згоди керівництва компанії-цілі. Недружні поглинання, проведені в рамках правового поля, не несуть негативних наслідків для господарської діяльності товариства, оскільки спрямовані на подальше співробітництво та розвиток в рамках об’єднаної компанії. Однак, в нашій країні процедура недружнього злиття та поглинання починається iз конференційного збору інформації щодо діяльності підприємства-цілі, керівники якого здогадуються про наміри рейдерів лише тоді, коли починаються ворожі дії зі сторони потенційних покупців. Найчастіше, вороже поглинання відбувається шляхом напівлегального привласнення активів або через процедуру банкрутства, не зважаючи на реальний 
стан справ підприємства-цілі, виробничі зв'язки та фінансові результати господарської діяльності. В цьому випадку мова йде саме про рейдерство, як елемент інституційної деформації економічної безпеки підприємства та інструмент перерозподілу власності. На думку авторів дослідження [11] головною відмінністю між «недружнім поглинанням» та «рейдерством» $\epsilon$ законність дій компанії, що намагається встановити контроль над активами підприємства-цілі. Навіть цілком законна операція стосовно поглинання активів підприємства стає рейдерським актом, якщо хоча 6 на одному 3 iï етапів застосовуються незаконні методи [15, с. 62]. Саме тому в свої роботах багато фахівців використовують таке поняття як «кримінальне рейдерство», що безпосередньо пов'язане із захопленням виробничих приміщень, обладнання, іншого майна підприємства 3 використанням лише незаконних методів $[2,4]$. Економічне рейдерство тісно пов'язують із хвилею насильства та ескалації агресії у суспільстві, що створює загрози інвестиційному клімату країни, знищує підприємницьку активність, негативно впливає на економічний розвиток держави в умовах необхідності дотримання умов Угоди про асоціацію України та Європейського Союзу [11]. I хоча, відповідно до оприлюдненого в 2017 p. Всесвітнім банком рейтингу країн, де легше всього вести бізнес, Україна піднялася на три пункти порівняно 3 минулим роком і зайняла 80 -е місце серед 190 країн, іноземні інвестори визнають, що без зв'язків вести справи в Україні невигідно та складно [16].

Аналіз наукової літератури дозволив зробити висновки про відсутність системного підходу до вивчення причин та процесів розвитку рейдерства в Україні. Водночас найбільш прийнятною та обгрунтованою, на думку автора, $\epsilon$ систематизація передумов розвитку рейдерства в Україні, що запропонована відомим українським економістом 3.С. Варналієм [1]. Учений виділяє такі основні причини поширення рейдерства в Україні: слабкість правової системи та судової влади; корумпованість органів влади; відсутність державних інститутів, що ефективно захищали б права власника; низький рівень правової культури; правовий нігілізм - як у суб'єктів господарювання, так і в представників органів влади; сумнівна передісторія приватизації певних об'єктів тощо. Деякі автори звертають увагу не тільки на зовнішні, але й на внутрішньгосподарські передумови поширення рейдерства в Україні. Наприклад, I. Паславський, аналізуючи причини виникнення рейдерства звертає увагу на «велику кількість помилок і порушень в управлінні підприємствами, тобто наявність значного резерву формальних приводів для рейдерських атак» [17, с. 159]. Лазуренко B.I. у роботі [18] вказує на об'єктивний характер передумов виникнення рейдерства, оскільки дане явище проявляється як форма перерозподілу засобів виробництва та, фактично, стає боротьбою за виробничі ресурси [18, с. 44]. Причинами рейдерства на думку вченого $\epsilon$ : виникнення корпоративних конфліктів; недосконалість законодавства; бажання інвесторів контролювати юридичну особу; невміле використання законодавчих положень та нормативноправових актів в боротьбі 3 рейдерами; наявність легальних та нелегальних методів, що дозволяють позбавити власників корпоративних прав або значно ïх обмежують; відсутність чітких критеріїв визначення недійсних корпоративних рішень, механізмів відповідальності менеджерів та контролюючих акціонерів; недостатня регламентація дій в системі ринку цінних паперів та процедури реєстрації юридичних осіб, наявність міжвідомчих суперечностей; недосконалість 
корпоративного права та процесуального законодавства; сумнівна історій приватизації об'єкта, відсутність реальних важелів забезпечення гарантій прав власності за наявності рішення суду; відсутність захисту інформації господарюючим суб'єктом; безкарність дій рейдерів та слабкість контролю зі сторони держави; неефективність судового контролю, корупція та ін.

В роботі [19] виокремлюються такі передумови розвитку рейдерства: нечітка, непрозора система реєстрації прав власності; високий рівень чиновницької корумпованості; високий ступінь недосконалості ринку корпоративного контролю на фоні зростання його сумарних значень у ВВП; недооцінка активів середніх і малих ВАТ, чиї акції не $\epsilon$ інструментом ринку корпоративного контролю, що призводить до зростання конкуренції при оцінці альтернатив та рівня витрат угод активів в секторі середніх і малих ВАТ. На думку автора, основними факторами, що вплинули на розвиток рейдерства в Україні, $є$ : недотримання правових норм в сфері захисту прав власності як на рівні окремих суб'єктів підприємницької діяльності, так i на державному рівні; високий рівень корупції серед представників правоохоронних органів, судової влади та дозвільних структур; недосконалість корпоративного законодавства, що провокує виникнення корпоративних конфліктів; неефективність ринкових інструментів перерозподілу власності та відсутність реально функціонуючого фондового ринку, що не дозволяє забезпечити вільний та прозорий обіг акцій; складана та непрозора система реєстрації прав власності; наявність великої кількості внутрішньогосподарських помилок, що створюють формальні приводи для атаки рейдерів на підприємство; відсутність системи систематичного моніторингу рейдерських загроз на підприємствах та низька інформаційна обізнаність керівництва підприємств щодо можливих методів та інструментів захисту від рейдерських атак; відсутність або формальна діяльність існуючих державних інституцій ефективного захисту прав власності в Україні.

Отже в умовах ринкової економіки функціонування і розвиток підприємств машинобудування обумовлені стабільною роботою механізму забезпечення економічної безпеки, а також ефективністю реалізованих підприємством заходів щодо захисту від рейдерських атак. Економічна безпека підприємства характеризується як стан захищеності його інтересів в умовах негативних впливів як внутрішніх так $\mathrm{i}$ зовнішніх загроз, що дозволяє забезпечити стабільне функціонування та збалансований, динамічний розвиток в поточному та перспективному періодах [20]. Загрози недружнього поглинання та рейдерського захоплення охопили абсолютно всі сфери економічної діяльності, що пояснюється низьким рівнем захисту інтересів господарюючих суб'єктів. Аналіз рейдерської діяльності у вітчизняній економіці показав, що для підприємств машинобудівної галузі спостерігається високий рівень загрози рейдерських захоплень, що $є$ наслідком дії цілої низки факторів. На деяких 3 них вже акцентувалася увага в дослідженні, на інших наголошується у працях таких відомих науковців, як: 3.С. Варналія [1], О.А. Бурбело [5], С.С. Молодецького [6], B.I. Лазуренко [18] та ін. Узагальнено загрози економічні безпеці вітчизняних підприємств машинобудування в напряму протидії рейдерству, а також шляхи їх вирішення наведено у табл. 1. (складено автором на основі узагальнення джерел [1$8]$ ). 
Загрози економічній безпещі підприємств машинобудування та шляхи їх усунення у напрямку протидї рейдерству

\begin{tabular}{|c|c|}
\hline Загрози економічної безпеці & Шляхи усунення наведених загроз \\
\hline 1 & 2 \\
\hline \multicolumn{2}{|r|}{ На державному рівні } \\
\hline $\begin{array}{l}\text { Недосконале нормативно- } \\
\text { правове забезпечення єдиної } \\
\text { державної політики у сфері } \\
\text { протидії рейдерству. }\end{array}$ & $\begin{array}{l}\text { Розробка нормативно-правових актів, спрямованих на } \\
\text { посилення захисту прав власності та визначення дій щодо } \\
\text { протидії рейдерству; розробка єдиних підходів до } \\
\text { визначення рейдерства, його ознак, встановлення чітких } \\
\text { принципів та механізмів захисту від рейдерських атак. }\end{array}$ \\
\hline $\begin{array}{l}\text { Високий рівень корупції в } \\
\text { державних, правоохоронних, } \\
\text { контролюючих та судових } \\
\text { органах влади, що покликані } \\
\text { протидіяти рейдерським схемам } \\
\text { захоплення підприємств. }\end{array}$ & $\begin{array}{l}\text { Протидія корупції з метою виключення можливостей } \\
\text { використання рейдерських схем перерозподілу власності, } \\
\text { активізація роботи спеціальних державних органів протидії } \\
\text { рейдерству, забезпечення належного виконання чинних } \\
\text { нормативно-правових актів в сфері корпоративного права та } \\
\text { антирейдерського законодавства. }\end{array}$ \\
\hline $\begin{array}{l}\text { Погіршення інвестиційного } \\
\text { клімату в країні, зниження } \\
\text { обсягів іноземних інвестицій, } \\
\text { зниження підприємницької } \\
\text { активності на негативний вплив } \\
\text { на економічний розвиток } \\
\text { держави. }\end{array}$ & $\begin{array}{l}\text { Впровадження системи моніторингу рейдерських атак, } \\
\text { аналіз і оцінка характеру реальних і потенційних } \\
\text { внутрішніх і зовнішніх загроз економічній безпеці } \\
\text { підприємств на державному рівні, адекватна реакція з боку } \\
\text { правоохоронних органів на звернення постраждалих; } \\
\text { зміцнення інституту власності. }\end{array}$ \\
\hline $\begin{array}{l}\text { Відсутність на рівні держави } \\
\text { єдиної системної методологї̈ } \\
\text { оцінювання загроз рейдерських } \\
\text { захоплень підприємств за } \\
\text { галузями. }\end{array}$ & $\begin{array}{l}\text { Вибір та обгрунтування методик оцінки рейдерських } \\
\text { захоплень вітчизняних підприємств та, зокрема, } \\
\text { промислових, з метою прийняття ефективних управлінських } \\
\text { рішень щодо їх захисту. }\end{array}$ \\
\hline \multicolumn{2}{|r|}{ На рівні підприємств } \\
\hline $\begin{array}{l}\text { Зниження рівня } \\
\text { конкурентоспроможності } \\
\text { продукції підприємства та } \\
\text { погіршення умов їі реалізації, } \\
\text { відтік висококваліфікованого } \\
\text { персоналу. }\end{array}$ & $\begin{array}{l}\text { Удосконалення внутрішньгосподарської системи розподілу } \\
\text { функцій та повноважень з метою посилення захисту } \\
\text { комерційної таємниці, налагодження ефективної взаємодії } \\
\text { між підрозділами підприємства, що здійснюють моніторинг } \\
\text { рейдерських загроз, створення сприятливих умов для } \\
\text { роботи персоналу підприємства, активізація роботи служби } \\
\text { безпеки підприємства. }\end{array}$ \\
\hline $\begin{array}{l}\text { Втрата господарської самос- } \\
\text { тійності та зниження ступеня } \\
\text { ефективності функціонування } \\
\text { підприємства, скорочення } \\
\text { прибутків, зниження } \\
\text { інвестиційної та інноваційної } \\
\text { активності підприємства. }\end{array}$ & $\begin{array}{l}\text { Реалізація заходів, спрямованих на нейтралізацію або } \\
\text { відшкодування понесених збитків шляхом формування } \\
\text { ефективного механізму зміцнення економічної безпеки та } \\
\text { системи протидії недружнім поглинанням на основі } \\
\text { впровадження методики оцінки ризику рейдерства. }\end{array}$ \\
\hline $\begin{array}{l}\text { Припинення діяльності через } \\
\text { навмисне доведення до } \\
\text { банкрутства, відсторонення від } \\
\text { управління керівництва та } \\
\text { перерозподіл активів. }\end{array}$ & $\begin{array}{l}\text { Постійний моніторинг укладених угод щодо розірвання } \\
\text { завідомо збиткових, економічно необгрунтованих } \\
\text { зобов'язань; відмова від сумнівним партнерів у випадках } \\
\text { надання гарантій, поруки, надання в заставу майна, що } \\
\text { серед іншого потребує впровадження системи превентивних } \\
\text { методів захисту від рейдерства. }\end{array}$ \\
\hline
\end{tabular}


Висновок. У роботах $[2-6,19]$ науковці зазначають, що незважаючи на загрозу рейдерства, труднощі, пов'язані із забезпеченням економічної безпеки, вітчизняний машинобудівний комплекс зберігає суттєвий базовий потенціал для подальшого розвитку, зокрема: значні виробничі потужності, високий рівень забезпечення кваліфікованими кадрами, сучасний науково-виробничий потенціал 3 таких наукоємних галузей машинобудування як аерокосмічна, електронна, виробництво засобів зв'язку, приладобудування, суднобудування та ін., привабливі природно-кліматичні умови та наявність різноманітних природничих ресурсів, які мають вирішальне значення для розвитку промисловості. Підвищення рівня економічної безпеки підприємств машинобудування у напрямку протидії рейдерству забезпечить їх розвиток в стратегічній перспективі. Розв'язання найвагоміших проблем діяльності підприємств машинобудування 3 урахуванням загроз рейдерського захоплення вимагає розробки та реалізації ефективного механізму забезпечення економічної безпеки, зокрема удосконалення теоретико-методичних основ 3 використання сучасних інструментів управління. Вирішення окреслених питань сприятиме формуванню механізму забезпечення економічної безпеки підприємств у напрямку протидії рейдерству, реалізація якого дозволить підвищити рівень конкурентоспроможності та економічної безпеки вітчизняних підприємств машинобудування.

\section{ПЕРЕЛІК ВИКОРИСТАНИХ ДЖЕРЕЛ}

1. Варналій 3.С. Економічна безпека України: проблеми та пріоритети зміцнення: [монографія] / 3.С. Варналій, Д.Д. Буркальцева, О.С. Саєнко. - К.: Знання України, 2011. - 299 с.

2. Економічна безпека: підручник/ авт. кол.; за ред. д-ра екон. наук, проф. О. Б. Жихор, д-ра екон. наук, проф. О. I. Барановського. - К.: УБС НБУ, 2015. - 467 c.

3. Согрина Н. С. Методика оценки риска недружественного поглощения (рейдерства) в трансформируемой экономике / Н. С. Согрина // Вестник Челябинского государственного университета. Экономика. Вып. 25. - 2010. - № 5 (186). - С. 166-172.

4. Киреев А. Рейдерство на рынке корпоративного контроля: результат эволюции силового предпринимательства / А. Киреев // Вопросы экономики. - 2007. - № 8. - С. 80-92.

5. Бурбело О.А. Рейдерство: витоки, процедури, способи запобігання: монограф. / О.А. Бурбело, Г.В. Козаченко, Ю.С. Погорелов, С.О. Бурбело; МВС України, Луган. держ. ун-т внутр. справ ім. Е.О. Дідоренка. - Луганськ: РВВ ЛДУВС ім. Е.О. Дідоренка, 2012. - 184 с.

6. Молодецький С. С. Виникнення та сучасний стан рейдерства в Україні / С.С. Молодецький // Вчені записки Університету «Крок». Серія «Економіка». - К. 2015. - № 35. - C. 11-18.

7. Сребник Б.В. Поглощение компаний и способы защиты от него / Б.В. Сребник // Финансы. - 2011. - №9. - С. 65 70.

8. Щеглов Ю.А. Экономические подходы оценки риска рейдерства в посткризисных условиях / Ю.А. Щеглов // Известия высших учебных заведений. Поволжский регион. Общественные науки. - 2013. - №2(26). - С. 171-179.

9. Зайцева І.Ю. Підвищення економічної безпеки автотранспортних підприємств в умовах розвитку недружніх поглинань / I Ю. Зайцева. - Харків: УкрДАЗТ, 2009. - 357 с.

10. Загальна кількість підприємств, що піддалися рейдерським захопленням за час президентства Януковича, становила близько 5 тисяч Антирейдерська асоціація [Електронний 
pecypc]. - Режим доступу: https://press.unian.ua/press/983434-zagalnakilkist-pidpriemstv-scho-piddalisyareyderskim-zahoplennyam-za-chasprezidentstva-yanukovicha-stanovila-blizko5-tisyach-antireyderska-asotsiatsiya.html

11. Моніторинг рейдерських атак в Україні за січень-лютий 2015 p. (відповідно до повідомлень ЗМІ) / Український інститут дослідження екстремізму [Електронний ресурс]. Режим доступу: http://uire.org.ua/wpcontent/uploads/2015/03/Reyderstvodoslidzhennya-UIRE.pdf

12. Чи почуваєте Ви себе захищено від...(перелік; динаміка, 2008-2009) / Центр Разумкова [Електронний ресурс]. Режим доступу: http://old.razumkov.org.ua/ukr/poll.php?poll_ id $=325$

13. Про акціонерні товариства: Закон України №514-VI[Электронный ресурс]. доступа:http://zakon3.rada.gov.ua/laws/show 1514-17

14. Федулова Л.І. Сучасні концепції менеджменту Навч. посібник / За. ред. дра екон. наук, проф. Л.І. Федулової. - К.: Центр учбової літератури, 2007. - 536 с.

15. Полушкин О.А. Рейдерство: пути решения актуальных проблем / O.A. Полушкин // Закон и право. - 2008. - № 2. - C. 62-65.

16. Ведение бизнеса 2017 / Всемирный банк [Электронный ресурс]. Режим

http://russian.doingbusiness.org/rankings

17. Паславський I. Основні етапи протидії українському бізнесу. Роль і позиції ЗМІ / I. Паславський // Вісник Львівського університету. - 2011. Вип.34. - С. 158-172.

18. Лазуренко В.И. Корпоративные конфликты. Рейдерство / В.И. Лазуренко, Ю.В. Лазуренко Под общ. ред. В.И. Лазуренко. - Донецк: Донбасс, 2011. - 588 c.

19. Тарханова

3.Э.

Функционирование института рейдерства в РФ: автореф. дис. канд. экон. наук: 08.00.01 / 3. Э. Тарханова; Сев.-Осет. гос. ун-т им. К.Л. Хетагурова. - Владикавказ. $23 \mathrm{c}$.

20. Писаревський M.I. Теоретичні основи формування сутності поняття «забезпечення економічної безпеки підприємства в умовах рейдерства» / M.I Писаревський // Науковий журнал БізнесІнформ. - Харків : ХНЕУ, 2017. - № 5. C. 154-159.

\title{
УДК 658.1
}

\section{КЛАСИФІКАЦІЯ ЗАТРАТ ПІДПРИЕМСТВА 3 МЕТОЮ ПРИЙНЯТТЯ УПРАВЛІНСЬКИХ РІШЕНЬ}

\author{
Радіонова Н. Й., к.е.н., доцент (КНУТД)
}

У статті розглянуті питання класифікаиії затрат підприємств з метою прийняття ефективних управлінських рішень. Показано види класифікаиії затрат за різними ознаками. Розглянуто значення дієвої класифікації затрат для підприємства. Розкрито підходи різних авторів щцодо розподілу затрат на певні категорії за відповідними ознаками класифікації.

Ключові слова: управління затратами, виробничі затрати, класифікація затрат, скорочення затрат, підприємство. 